\title{
PREVALENCE AND CLINICAL STUDY OF PREGNANT WOMEN WITH HEPATITIS B INFECTION- AN INSTITUTIONAL EXPERIENCE
}

\author{
Roopa A. K1․ K. Aravind ${ }^{2}$
}

${ }_{1}^{1}$ Assistant Professor, Department of Obstetrics \& Gynaecology, KIMS, Hubli.

${ }^{2}$ Associate Professor, Department of Gastroenterology, KIMS, Hubli.

\section{ABSTRACT}

\section{BACKGROUND}

Hepatitis B Virus infection is a common public health problem in India. During pregnancy, there is risk of exacerbation and vertical transmission to infant. The purpose of this study is to assess the prevalence and Pregnancy outcome in women with Hepatitis B infection.

\section{MATERIALS AND METHODS}

149 women with Hepatitis B (HBsAg Positive) were retrospectively studied and their obstetric outcome analysed.

\section{RESULTS}

The prevalence of Hepatitis B was 1.4\%, the average age of mother being 27 years. Amongst the study population 107 (71.81\%) had vaginal delivery, 42 (28.19\%) had LSCS. Associated obstetric complications were seen in 45(30.2\%), the major ones being pregnancy induced hypertension in $16(10.74 \%)$, premature rupture of membranes in 11 (7.38\%), meconium stained liquor in 8 (5.37\%), anaemia in 8 (5.37\%). Average birth weight $2.5 \mathrm{KG}$. NICU admission were 8 mainly for RDS, meconium aspiration and septicaemia. Stillbirths were $4(2.6 \%)$.

\section{CONCLUSION}

Hepatitis B Positive mothers were asymptomatic and had good Obstetric outcome. LSCS rate and Obstetric complications were comparable with Hepatitis B Negative mothers. Active and passive immunisation of the neonate is the main stay of management.

\section{KEYWORDS}

HBsAg Positive, Hepatitis B Infection, Pregnancy, Maternal and Foetal Outcome.

HOW TO CITE THIS ARTICLE: Roopa AK, Aravind K. Prevalence and clinical study of pregnant women with hepatitis b infectionan institutional experience. J. Evolution Med. Dent. Sci. 2017;6(11):888-890, DOI: 10.14260/Jemds/2017/190

\section{BACKGROUND}

Hepatitis B is endemic in Asian and African countries. Prevalence varies from 0.1 to $20 \%$ worldwide. There are 400 million chronic carriers in the world.[1] Indian subcontinent comes under intermediate prevalence. Carrier rate of hepatitis B varies in different regions of India. The overall carrier rate is often quoted as being $4.7 \% .{ }^{[2]}$ Lodha, et al[3] did a systematic review of literature and concluded that the true prevalence of Hepatitis B in India was 1 to $2 \%$. Recent study shows a prevalence of 0.5 to $1.01 \%$ in India.[4,5] It causes acute and chronic hepatitis, cirrhosis and Hepatocellular Carcinoma.[6] Vertical transmission is one of the predominant means of transmission from mother to child in developing countries. The other groups at risk for hepatitis B infection are IV drug abusers, partners of infected individuals and those who frequently receive blood products.

CDC and advisory committee on immunisation practices and ACOG have all strongly recommended universal HBsAg screening of pregnant woman to prevent perinatal transmission.

Financial or Other, Competing Interest: None.

Submission 14-01-2017, Peer Review 26-01-2017,

Acceptance 28-01-2017, Published 06-02-2017.

Corresponding Author:

Dr. Roopa A. K,

Assistant Professor,

Department of Obstetrics and Gynaecology,

KIMS, Hubli-580022.

E-mail:draravindk@yahoo.com

DOI: $10.14260 /$ jemds $/ 2017 / 190$
Most HBV infections identified during pregnancy are chronic asymptomatic and diagnosed by routine prenatal serological screening.

After acute infection, up to $12 \%$ of affected adults and up to $90 \%$ of infected neonates may become chronic carriers. When the mother is positive for viral DNA in her serum, vertical transmission rate is up to $90 \%$.

$\mathrm{HBeAg}$ positivity suggests high infective status. $\mathrm{HBeAb}$ positivity suggests low risk of spreading infection as compared to HBeAg positive.

Transplacental viral infection is uncommon and most neonatal infections are transmitted by peripartum exposure. There is no evidence to suggest that caesarean delivery lowers the risk.[7]

Although the virus is present in breast milk, incidence of transmission is not lowered by formula feeding.

Adverse pregnancy outcome like PIH, GDM, Preterm labour and LBW were documented in few studies.

RCOG Suggests Further Evaluation of Patients Who Test Positive for HBsAg. These are-

- HBV serology - including HBeAg status.

- HBV DNA level.

- Delta virus testing.

- HCV testing.

- Liver function tests, including tests of synthetic function (INR).

- Liver ultrasound. 
NICE Guidelines suggest following steps in patients who test positive for HBsAg.

Discuss with pregnant women the benefits and risks of antiviral treatment for them and their baby.

Offer tenofovir disoproxil to women with HBV DNA greater than $10^{7} \mathrm{IU} / \mathrm{ml}$ in the third trimester to reduce the risk of transmission of HBV to the baby.

Monitor quantitative HBV DNA 2 months after starting tenofovir disoproxil and ALT monthly after the birth to detect postnatal HBV flares in the woman.

Stop tenofovir disoproxil 4 to 12 weeks after the birth unless the mother meets criteria for long-term treatment.

Offer active and passive hepatitis B immunisation in infants and follow up in line with the guidance bel.

In our setup, asymptomatic HBsAg positive patients are not subjected to further immunological evaluation due to economic constraints and neonatal immunoprophylaxis given to all. We tried to assess overall obstetric outcome in this population to assess institutional management in Indian scenario.

\section{MATERIALS AND METHODS}

It is a retrospective observational study conducted at KIMS, a tertiary care institute situated in North Karnataka, India catering to the people of surrounding 5 Districts and conducting 10,000-11000 deliveries per year. All the antenatal cases with HBsAg positive admitted for delivery during one year i.e. from Jan 2016 to Dec 2016 were included in the study. Rapid diagnostic test was used. All case sheets were studied in detail (Excel sheet prepared) and data analysed.

\section{RESULTS}

Total no of deliveries during the period were 10539. HBsAg positive patients were 149 (Prevalence 1.4\%) and 10390 were HBsAg Negative. Average gestational age was 27 years (Range from 19 to 35 years). Among them 56 (37.58\%) cases were booked with us, $71(47.65 \%)$ cases were booked elsewhere and referred, $22(14.77 \%)$ cases were unbooked. Out of 149, Primigravida were 53 (35.58\%), 2nd gravida were $76(51 \%)$, third (three and above) gravida were 20 (13.42\%). 107 (71.81\%) patients were delivered vaginally, and 42 (28.19\%) underwent LSCS. Among them, term deliveries were 141 (94.63\%) and preterm were 8 (5.37\%).

Obstetric complications observed: pregnancy induced hypertension (PIH) 16 (10.47\%), premature rupture of membrane (PROM) 11 (7.38\%), meconium stained amniotic fluid (MSAF) 8 (5.37\%) and anaemia 8 (5.37\%). No cases of gestational diabetes mellitus (GDM) or Low birth weight (LBW) were noted. 98 cases [65.77\%] did not have any associated obstetric complications. Average birth weight was 2.5 KG (Range 1.8 to $3.5 \mathrm{KGs}$ ). Eight babies were admitted to NICU for Respiratory distress, meconium aspiration and septicaemia. 4 were Intra Uterine Foetal Death (IUFD).

\begin{tabular}{|c|c|}
\hline Type & $\begin{array}{c}\text { Number (Percentage) } \\
\mathrm{N}=149\end{array}$ \\
\hline Booked with us & $56(37.58 \%)$ \\
\hline Booked Elsewhere & $71(47.65 \%)$ \\
\hline Un booked & $22(14.77 \%)$ \\
\hline
\end{tabular}

\begin{tabular}{|c|c|}
\hline Gravid Status & Number (Percentage) $\mathbf{N = 1 4 9}$ \\
\hline Primi & $53(35.58 \%)$ \\
\hline Second & $76(51 \%)$ \\
\hline Third and above & $20(13.42 \%)$ \\
\hline \multicolumn{2}{|c|}{ Table 2. Gravid status of study population } \\
\hline
\end{tabular}

\begin{tabular}{|c|c|}
\hline Type & Number (Percentage) $\mathbf{N = 1 4 9}$ \\
\hline Term & $141(94.63 \%)$ \\
\hline Preterm & $8(5.37 \%)$ \\
\hline \multicolumn{2}{|c|}{ Table 3. Foetal maturity population } \\
\hline
\end{tabular}

\begin{tabular}{|c|c|c|}
\hline $\begin{array}{c}\text { Mode of } \\
\text { Delivery }\end{array}$ & $\begin{array}{c}\text { Number (Percentage) } \\
\text { N=149 } \\
\text { HBsAg Positive }\end{array}$ & $\begin{array}{c}\text { Number (Percentage) } \\
\mathbf{N = 1 0 3 9 0} \\
\text { Non HBsAg Positive }\end{array}$ \\
\hline $\begin{array}{c}\text { Vaginal } \\
\text { Delivery }\end{array}$ & $107(71.81 \%)$ & $6880(66.22 \%)$ \\
\hline LSCS & $42(28.19 \%)$ & $3510(33.78 \%)$ \\
\hline \multicolumn{3}{|c|}{ Table 4. Mode of Delivery } \\
\hline
\end{tabular}

\begin{tabular}{|c|c|c|}
\hline $\begin{array}{c}\text { Obstetric } \\
\text { Complications }\end{array}$ & $\begin{array}{c}\text { Number } \\
\text { (Percentage) } \\
\text { N=149 } \\
\text { HBsAg Positive }\end{array}$ & $\begin{array}{c}\text { Number } \\
\text { (Percentage) } \\
\text { N=10390 } \\
\text { Non HBsAg Positive }\end{array}$ \\
\hline PIH & $16(10.74 \%)$ & $1995(19.2 \%)$ \\
\hline PROM & $11(7.38 \%)$ & $663(6.38 \%)$ \\
\hline MSAF & $8(5.37 \%)$ & $90(0.87 \%)$ \\
\hline Anaemia & $8(5.37 \%)$ & $2432(23.41 \%)$ \\
\hline IUFD & $4(2.68 \%)$ & $50(0.48)$ \\
\hline \multicolumn{2}{|c|}{ Table 5. Obstetric complications } \\
\hline
\end{tabular}

\section{DISCUSSION}

In our study the prevalence rate is $1.4 \%$. The prevalence rate is slightly on higher side as it is a tertiary referral centre where high risk cases get pooled up. Routine anti natal screening for hepatitis B is done in all cases in our institute.

National Institute for Health and Clinical Excellence advises against elective Caesarean section for the prevention of mother-to-child transmission of hepatitis B, as evidence on this issue is insufficient.

The incidence of PIH in our study is high compared to other studies. This can be explained by the fact that this region is endemic for PIH. In our study incidence of PIH among HBsAg positive women was lower than non HBsAg positive women. It is comparable to the study conducted by To et al, where there was a lower risk for gestational hypertension and pre-eclampsia than in non-carrier.[8]

Our study did not suggest a higher rate of preterm delivery. Whereas a study of Tse KY et al which suggests an increased risk of preterm delivery in HBsAg positive woman. ${ }^{[9]}$

Average birth weight in our study population is $2.5 \mathrm{~kg}$. In a study done by Shui-Lam MAK et al 'HBsAg carriers delivered slightly larger babies'. In our study, there were no cases of GDM. However, according to the Hong Kong College of Obstetricians and Gynaecologists, HBsAg carriage is regarded as a risk factor for GDM in Asian women.

A study done in Canada showed that hepatitis is not associated with increase in abortion, still birth and congenital malformation. However, prematurity is likely to increase if hepatitis is acquired in the last trimester.[10] 
Some studies have also demonstrated that infants born to mothers with acute infection during pregnancy have low birth weights.[11]

In our study, all cases were asymptomatic. LFT \& PT INR were done in only booked cases and they were normal in all the cases.[10]

\section{CONCLUSION}

Our study suggested a point prevalence of $1.4 \%$. Other studies have found prevalence rates ranging from $0.5 \%$ to $15.9 \%$. Incidence varies from place to place and hospital to hospital. And they being hospital studies, they are not representative of prevalence in general population. Prevalence pattern is skewed depending on referral patterns. Obstetric outcome in HBsAg positive women is similar to HBsAg negative population.

Universal screening of all pregnant women and active and passive immunisation of the neonate are important

\section{REFERENCES}

[1] WHO. Hepatitis B. Fact sheet no: 204. Geneva, Switzerland: World Health Organization 2011.

[2] Indian Association for Study of the Liver. Hepatitis B in India; therapeutic options and prevention strategies Consensus statement. Indian J Gastroenterol 2000;19:C4-66.

[3] Lodha R, Jain Y, Anand K, et al. Hepatitis B in India: a review of disease epidemiology. Indian Pediatr 2001;38(4):349-71.
[4] Rajendiran S, Gopalan U, Jayakumar K. Seroprevalence of hepatitis B infection among pregnant women in South India. Int J Reprod Contracept Obstet Gynecol 2017;6(1):249-51.

[5] Katke RD. The impact of maternal HbsAg carrier status on pregnancy outcomes: an institutional experience. Gynecol Obstet 2015;5:5.

[6] Zhu R, Zhang HP, Yu H, et al. Hepatitis B virus mutations associated with in situ expression of hepatitis B core antigen, viral load and prognosis in chronic hepatitis $\mathrm{B}$ patients. Pathol Res Pract 2008;204(10):731-42.

[7] American College of Obstetricians and Gynecologists. ACOG practice bulletin no. 86: viral hepatitis in pregnancy. Obstet Gynecol 2007;110(4):941-56.

[8] To WW, Cheung W, Mok KM. Hepatitis B surface antigen carrier status and its correlation to gestational hypertension. Aust N Z J Obstet Gynaecol 2003;43(2):119-22.

[9] Tse KY, Ho LF, Lao T. The impact of maternal HBsAg carrier status on pregnancy outcomes: a case-control study. J Hepatol 2005;43(5):771-5.

[10] Levy M, Koren G. Hepatitis B vaccine in pregnancy: maternal and fetal safety. Am J Perinatol 1991;8(3):227-32.

[11] Uyar Y, Cabar C, Balci A. Seroprevalence of hepatitis B virus among pregnant women in Northern Turkey. Hepatitis Monthly 2009;9(2):146-9. 